\title{
The suggestions of teachers for faculty development in undergraduate medical education of Bangladesh
}

\author{
Dr. Shamima Rahman ${ }^{1}$, Dr. Mossammat Nigar Sultana ${ }^{2}$, Dr. Farhana Noman ${ }^{3}$ Dr, Rokeya Zaman ${ }^{4}$, Dr. Abida Sultana ${ }^{5}$ Prof. Dr. Soofia Khatoon ${ }^{6}$
}

\begin{abstract}
This descriptive cross sectional study was carried out from July 2015 to June 2016 to identify the teachers' views regarding the suggested responsibilities of concerned authorities in faculty development (FD )in undergraduate medical education of Bangladesh. A semistructured self-administered questionnaire was used for collecting data from 103 teachers of eight Government and Non- Government medical colleges located within and outside Dhaka. They agreed with the different suggested role of the departments, institutes, teachers' associations, Director Medical Education (DME), and Ministry of Health \& Family Welfare (MOHFW) for FD. Among the suggestions the most agreed roles were 'Make an outline for participation of CME \& CPD' for promotion by MOHFW ( $80 \%$ ); 'Arrangement of CME \& CPD' by the institutes (79\%); 'Arrangement of CME \& CPD' by the teachers association (76\%); 'Supervision of faculty development' by the DME (76\%); 'Distribution of personal review form (54\%)', 'Collection of personal review form (54\%)' and 'Time management of faculty development $(54 \%)$ ' by the departments. It is recommended that the concerned authorizes should play their own role appropriately for proper implementation of the FD.
\end{abstract}

Keywords: Faculty development, Undergraduate medical education, Quality Assurance of Scheme of medical education.

\section{Introduction}

Faculty development or staff development has become an increasingly important component of medical education. It was once assumed that a competent basic or clinical doctor would naturally be an efficient teacher, it is now acknowledged that appropriate knowledge and skill for teaching is essential. It became apparent that teaching was not an innate gift. Besides, it requires systematic process and academic supports to develop necessary skills and art of teaching, With emergence of increasing complexity and pressures of healthcare delivery, new approaches to teaching and learning, and competing demands on teachers' time the faculty members require a broad range of teaching and learning competencies that can be used in diverse settings (Benor 2000).

There is also a need for creation new strategy to prepare the

1. Dr. Shamima Rahman, Assistant Professor ( Gynae and Obstetrics), Colonel Malek Medical College, Manikgonj.

2. Dr. MossammatNigar Sultana, Junior Consultant (Gynae and Obstetrics), Jinjira 20 Bedded Hospital, Upazila Health Complex, Keraniganj

3. Dr. FarhanaNoman, Lecturer, Dhaka Central International Medical College, Dhaka.

4. Dr, Rokeya Zaman, Assistant Professor (conservative Dentistry), Cumilla Medical College, Cumilla

5. Dr. Abida Sultana, Senior Consultant, Department of Gynae and Obstetrics, Dhaka Medical College, Dhaka

6. Prof. Dr. Soofia Khatoon, Head of the Department (Paediatrics), Center for Women and Child Health, Dhaka.

Address of correspondence:

Dr. Shamima Rahman, MS (Gynaecology and Obstetrics),

MMEd, Asstt. Professor (Gynae \& Obs)

Colonel Malek Medical College, Manikgonj

Email: zamanass16@gmail.com future healthcare professionals. This requires adoption of new curricula, novel pedagogies and innovative forms of faculty members. The faculty members are the most important assets of an academic institution (Whitcomb 2003).

Faculty development is also meant to improve practice and manage change by enhancing individual strengths and abilities as well as organizational capacities and culture (Bligh 2005).

In the $80 \mathrm{~s}$ and $90 \mathrm{~s}$, reformation of educational strategy to more student-centred and self-directed learning required a transformation of the teacher, from a didactic provider of knowledge to a facilitator of student centred learning (Entwistle \& Ramsden 1983). To make this transition, teachers needed new skills, which required training. The beginning of the new millennium brought 'outcomes-based education', with competencies being identified for graduating medical students (Harden et al. 1999).

Faculty development followed suite, and the various roles of the medical teacher, from clinical expert to mentor and role model, were further expanded and defined (Harden \& Crosby 2000). Not long afterwards, Hesketh et al. (2001), using the three circle model (Harden et al. 1999), defined the intelligences of an excellent clinical teacher. These twelve intelligences embodied knowledge, skills and attitudes, such that the right person was doing the correct procedure or task properly with the appropriate attitude and behavior.

In our country we have many problems in our way to improve our faculty members to meet the challenges of present day. The present medical education has incompatible mission and vision, defective curriculum, defective admission policy, ineffective instructional methods, inadequate exposure to clinical training, lack of qualified teaching staff and resources (Majumder 2003).

Bangladesh Journal of Medical Education 2019;10(1):2-5. C 2019 Rahman et al., publisher and licensee Association for Medical Education. This is an Open Access article which permits unrestricted non-commercial use, provided the original work is properly cited. 
Over the last few years faculty development has become important issue particularly in medical education. We are now living in the rapidly changing world. Societal trends towards increased accountability have led to requirement of quality assurance and academic standard in medical education. Accrediting body impose new standard. For achievement of that standard improvement of faculty development program is demand of present circumstances (Srinivas 2009).

In consideration of above mentioned facts, the researcher in this study had tried to find out the suggestions of teachers about improvement and strengthening of present faculty development program. The result of analysis of this study may play some part for improvement and will meet the need of future days demand.

\section{Methodology}

This was a descriptive type of cross-sectional study and carried out from July 2015 to June 2016 . The objective of the study was to find out the suggestions of the teachers about the responsibilities of concerned authorities for improvement of faculty development in undergraduate medical education of Bangladesh. This study was conducted in the eight conveniently selected medical colleges of Bangladesh, of these four had government ownership (two located at Dhaka city, two located outside Dhaka city) and four had nongovernment ownership (two located at Dhaka city, two located outside Dhaka city). A total of one hundred and three (103) teachers (lecturer to professor) participated voluntarily from eleven major departments as per the "Curriculum for Undergraduate Medical Education in Bangladesh -Updated 2012".A semi- structured self- administered questionnaire was used to collect data from teachers of medical colleges. Written permission was taken properly from the principal of the colleges prior to data collection. All questionnaires were distributed by the researcher herselfto the teachers' who were willing to participate in the study. Initially the purpose of the study and the questionnaire was briefed to the respondents. The questionnaires were filled up by the teachers in presence of the researcher and necessary clarification was given about any doubts raised by the respondents. Quantitative part of data checked \& edited after collection. Data processed \& analyzed by using SPSS software package. Data was presented in the form of table \& graphs. Anonymity of the respondents and medical colleges was maintained.

\section{Results}

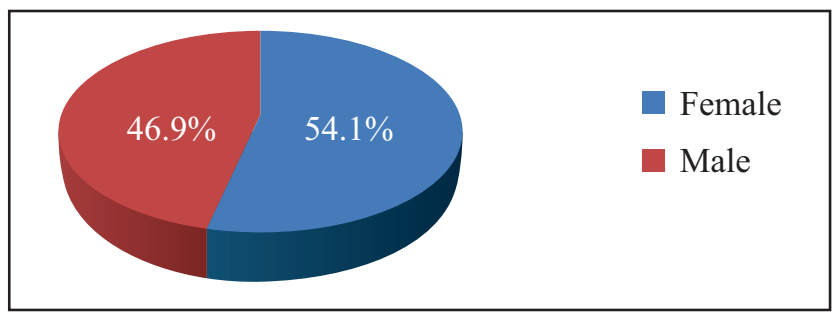

Figure 1: Distribution of the teachers by their gender $(\mathrm{n}=181)$
Figure 1 showed that among the 181 teachers $54 \%$ were female and $47 \%$ were male.

Table 1: Distribution of the teachers by their designation and educational degree $(\mathrm{n}=181)$

\begin{tabular}{|c|c|c|c|c|c|}
\hline \multirow{2}{*}{$\begin{array}{l}\text { Educational } \\
\text { degree }\end{array}$} & \multicolumn{4}{|c|}{ Designation of teachers (Frequency) } & \multirow{2}{*}{$\begin{array}{l}\text { Total } \\
(\%)\end{array}$} \\
\hline & professor & $\begin{array}{l}\text { Associate } \\
\text { Professor }\end{array}$ & $\begin{array}{l}\text { Assistant } \\
\text { Professor }\end{array}$ & Lecturer & \\
\hline $\begin{array}{l}\text { Only } \\
\text { MBBS }\end{array}$ & 0 & 0 & 0 & 43 & $\begin{array}{c}43 \\
(23.8)\end{array}$ \\
\hline Diploma & 0 & 4 & 3 & 4 & $\begin{array}{c}12 \\
(0.7)\end{array}$ \\
\hline Masters & 2 & 7 & 21 & 3 & $\begin{array}{c}33 \\
(18.2)\end{array}$ \\
\hline Fellowship & 4 & 14 & 20 & 3 & $\begin{array}{c}41 \\
(22.7)\end{array}$ \\
\hline Mphil & 2 & 17 & 23 & 2 & $\begin{array}{c}44 \\
(24.3)\end{array}$ \\
\hline $\mathrm{PhD}$ & 5 & 3 & 0 & 0 & $\begin{array}{c}8 \\
(0.04)\end{array}$ \\
\hline Total & 13 & 45 & 67 & 55 & $\begin{array}{c}181 \\
(100 \%)\end{array}$ \\
\hline
\end{tabular}

Table 1 showed the designation of the teachers and educational degrees. Of them 67 were Assistant professors, 55 were lecturers, 45 were Associate Professors and only 13 were professors. Of them 43 had no post-graduation and they all were lecturers.

Table 2: Distribution of teachers by their agreement about the suggested responsibilities of department in faculty development (FD) $(\mathrm{n}=181)$

\begin{tabular}{lcc}
\hline Responsibilities of departmentsin FD & Frequency & Percent* \\
\hline Distribution of personal review form & 98 & 54.1 \\
Collection of personal review form & 98 & 54.1 \\
$\begin{array}{l}\text { Time management of faculty } \\
\text { development }\end{array}$ & 98 & 54.1 \\
$\begin{array}{l}\text { Resource management for FD } \\
\text { Fulfillment of CPD*\& CME } \\
\text { for future promotion }\end{array}$ & 82 & 45.3 \\
\hline
\end{tabular}

* Multiple responses

$\mathrm{CPD}^{*}=$ Continuing Professional Development

$\mathrm{CME}^{\varphi}$ : Continuing Medical Education

Table 2 showed out of 181 teachers about 54\% agreed with 'Distribution of personal review form', 'Collection of personal review form' and 'Time management of faculty development' as suggested responsibilities of the departments in faculty development (FD). On the other hand, $45 \%$ and $30 \%$ teachers agreed with 'Resource management for FD' and 'Fulfillment of CME \& CPD credits

Bangladesh Journal of Medical Education 2019;10(1):2-5 
promotion' as suggested responsibilities of the departments in FD.

Table 3: Distribution of teachers by their agreement about the suggested responsibilities of institute in faculty development $(\mathrm{FD})(\mathrm{n}=181)$

\begin{tabular}{lcc}
\hline Responsibilities of institute in FD & Frequency & Percent* \\
\hline $\begin{array}{l}\text { Arrangement of CME\& CPD activity } \\
\text { Monitoring of faculty development }\end{array}$ & 142 & 79.3 \\
$\begin{array}{l}\text { programme } \\
\text { Selection of teacher for CPD\& CME } \\
\text { according to priority }\end{array}$ & 62 & 59.2 \\
\end{tabular}

* Multiple responses

Table 3 showed out of 181 teachers about $79 \%, 59 \%$ and $34 \%$ teachers agreed with 'Arrangement of CME \& CPD activity', 'Monitoring of faculty development programme' and 'Selection of teacher for CME \& CPD according to priority' as suggested responsibilities of the departments in FD respectively.

Table 4: Distribution of teachers by their agreement about the responsibilities of teachers association of the college in faculty development (FD) $(n=181)$

\begin{tabular}{lcc}
\hline $\begin{array}{l}\text { Responsibilities of the teacher } \\
\text { association for FD }\end{array}$ & Frequency & Percent* \\
\hline $\begin{array}{l}\text { Arrangement of CPD\& CME activity } \\
\text { Conduct need assessment \& select }\end{array}$ & 137 & 75.6 \\
topic for CPD \& CME & 102 & 56.3 \\
$\begin{array}{l}\text { Set standard for comparison with } \\
\text { international standard }\end{array}$ & 76 & 41.9 \\
\hline
\end{tabular}

* Multiple responses

Table 4 showed out of 181 teachers about $76 \%, 59 \%$ and $42 \%$ teachers agreed with 'Arrangement of CME \& CPD activity', 'Conduct need assessment \& select topic for CME \& CPD accordingly' and 'Set standard for comparison with international standard' as suggested responsibilities of the departments in FD respectively.

Table 5: Distribution of teachers by their agreement about the responsibilities of Director Medical Education (DME) in faculty development (FD) $(n=181)$

\begin{tabular}{lcc}
\hline Responsibilities of DME inFD & Frequency & Percent* \\
\hline Supervision of faculty development & 131 & 72.2 \\
$\begin{array}{l}\text { Supervision of teacher evaluation } \\
\begin{array}{l}\text { Set outlines for obligatory } \\
\text { conduction of CME \& CPD }\end{array}\end{array}$ & 120 & 69.8 \\
$\begin{array}{l}\text { Set outlines fund for faculty } \\
\text { development programme }\end{array}$ & 72 & 57.6 \\
\hline
\end{tabular}

* Multiple responses
Table 5 showed out of 181 teachers about $76 \%, 70 \%, 58 \%$ and $42 \%$ teachers agreed with 'Supervision of faculty development', 'Supervision of teacher evaluation',' Set outlines for obligatory conduction of CME \& CPD' and 'Set outlines fund for faculty development programme' as suggested responsibilities of the departments inFDrespectively.

Table 6: Distribution of teachers by their agreement about the responsibilities of Ministry of Health \& Family Welfare $(\mathrm{MOHFW})$ in faculty development $(\mathrm{FD})(\mathrm{n}=181)$

\begin{tabular}{lcc}
\hline Responsibilities of MOHFW in FD & Frequency & Percent* \\
\hline $\begin{array}{l}\text { Make outline for participation of } \\
\text { CME \& CPD for promotion }\end{array}$ & 144 & 79.56 \\
$\begin{array}{l}\text { Make outline for teacher evaluation } \\
\begin{array}{l}\text { Selection of participant for training } \\
\text { abroad }\end{array}\end{array}$ & 114 & 62.98 \\
$\begin{array}{l}\text { Make list of persons who will } \\
\text { conduct teacher evaluation }\end{array}$ & 49 & 27.07 \\
$\begin{array}{l}\text { Determine/set the time interval of } \\
\text { teacher evaluation }\end{array}$ & 38 & 20.99 \\
\hline
\end{tabular}

* Multiple responses

Table 6showed out of 181 teachers about $80 \%, 63 \%$, and $52 \%$ teachers agreed with 'Make outline for participation of CME \& CPD D program for e promotion', 'Make outline for teacher evaluation' and 'Selection of participant for training abroad' are the responsibilities of Ministry of Health \& Family Welfareas suggested responsibilities of the departments in FD respectively. On the other hand, about $27 \%$ and $21 \%$ teachers agreed with 'Make list of persons who will conduct teacher evaluation' and 'Determine/set the time interval of teacher evaluation' are the responsibilities of the Ministry of Health \& Family Welfare as suggested responsibilities of the departments in FD respectively.

\section{Discussion}

Role of Departmentsin faculty development (FD): The present study found that more than half of the teachers (54\%) had agreed with'Distribution and collection of personal review form' and 'time management of faculty development'as the main responsibilities of the departments in FD (Table 3). Halder (2015) in his study on National Quality Assurance Scheme (QAS) for the medical college of Bangladesh found that $28.6 \%$ of college authority suggested to improve teaching learning to strengthen the faculty development and review programme and $14.3 \%$ of authority suggested proper monitoring and supervision. Clark (2004) displayed that over $75 \%$ of respondents reported that their programs needed at least some development in administrative structure, content, teaching methods, intensity. At least $50 \%$ reported the need for moderate to major improvement in content, evaluation, or administrative structure of their FD programs. 
Role of institutes in FD: The present study found that about $79 \%$ teachershad agreed with 'Arrangement of CME \& CPD activity' and59\% of them suggestedfor 'Monitoring of faculty development programme'as major responsibilities of the institutes inFD(Table 4). Adkholi (2009) suggested in his study that periodic teacher training should form an essential requirement for career development, promotion and empanelment as examiners. Teachers should be encouraged to attend faculty development programmes by offering leave of absence. Award, accreditation, scholarship or such other facilities for attending workshops and conferences may increase interest among faculty. More recently, it wasfound that faculty development programmes yielded positive outcomes in teacher practices and student learning and it is vital to the institutional mission and goals (Elliott and Oliver, 2016).

Role of teachers' associationsin FD: It was revealed in this study that about three-forth (76\%) teachers had agreed with 'Arrangement of CPD\& CME activity' and 56\% teachers had suggestedfor to 'Conduct need assessment \& select topic for CPD\& CME' as main responsibilities of teachers' associations of the college in $\mathrm{FD}$ (Table 5).Adkoli (2009) suggested in his study that certification for participation, travel support for attending conferences may increase participation in faculty development activities. Moreover, a study recommendedthat the incorporation of learning and teaching professionalism into the FD transform the clinical experiences of teachers into an academic institutional reform (Al Eraky MM et al. 2015).

Role of Director Medical Education in FD: The present study showed that three-fourth $(76 \%)$ of the teachers had agreed with 'Supervision of faculty development', about $70 \%$ of them had agreed with 'Supervision of teacher evaluation' and $58 \%$ had agreed with 'Set an outlines for obligatory conduction of CPD\& CME' as major responsibilities of Director Medical Education in FD (Table 6). Srinivas (2009) suggested in his study that earlier World Health Organization (WHO), and other international organizations offered regularly fellowships for study tours and for advanced training in reputed centres in the UK, USA, and Australia. National agencies as well international agencies like World Health Organization should revive fellowships for study tours to reputed medical education centers within and outside country. This Steps may encourage specialization in education.

Role of Ministry of Health \& Family Welfare (MOHFW) in FD:The present study foundthat $80 \%$ of the teachers had agreed with 'Make an outline for participation of CPD \&CME for promotion', about $63 \%$ ofthem had agreed with 'Make an outline for teacher evaluation' and 53\% had agreed with 'Selection of participant for training abroad' as major responsibilities of Ministry of Health \& Family Welfare in FD (Table 6).Srinivas (2009) suggested in his study that Central Government, State governments, Health Sciences Universities, Medical Council of India and National Board of Examinations should take proactive role in FD. They should identify active medical units and support them for FD.

\section{Conclusions}

This study was found that different responsibilities of departments, institutes, teachers' associations, Director Medical Education and Ministry of Health \& Family Welfare (MOHFW) are more or less important for proper execution of faculty development in the country.

\section{References:}

1. Adkoli, B.andSood, R.(2009). Faculty development and medical units of India : A survey.The national medical journal of India, 22(1), pp.28-32.

2. Al-Eraky, M.M., Donkers, J., Wajid, G. and Van Merrienboer, J.J. (2015).Faculty development for learning and teaching of medical professionalism.Med Teach, 37(1), S40-6.

3. Bligh, J.(2005).Faculty development.Medical education, 39 (2), pp. 120-1.

4. Clark, J.M., Houston, T.K., Kolodner, K., Branch, W.T., Levine, R.B. and Kern, D.E. (2004).Teaching the teachers: national survey of faculty development in departments of medicine of U.S. teaching hospitals.J Gen Int Med, 19(3), pp.205-14.

5. Entwistle, N.J. (1991). Approaches to learning and perceptions of the learning environment.Higher Education, 22(3), pp.201-4.

6. Elliott, R.W., Oliver, D.E.(2016). Linking Faculty Development to Community College Student Achievement: A Mixed Methods Approach. Community College Journal of Research and Practice, 40(2), pp. 85-99.

7. Halder, B.B.(2015). Current practice of Quality Assurance Scheme in different medical colleges of Bangladesh, MMEd thesis, Bangabandhu Shiikh Mujib Medical University.pp.58- 60 .

8. Harden, R.M. (1999). Stress, pressure and burnout in teachers: is the swan exhausted? Med Teach , 21(3), pp.245-7.

9. Harden, R.M.(2000). Evolution or revolution and the future of medical education: replacing the oak tree. Med Teach, 22(5), pp.435-42.

10. Majumder,M.A.A..(2003). Medical education in Bangladesh past successes, future challenges. Bangladesh Medical Journal,32, pp. 37-9.

11. Srinivas, D.K. andAdkoli, B.V., (2009), Faculty development in medical education in India: The need of the day, Al Ameen J Med S ci, 2(1), pp. 6-13.

12. Whitcomb, M.(2003). The medical school's faculty is its most important asset, Acad Med vol.78 no. 2 pp.117-118. 